\title{
SOME ASPECTS OF SAFETY MANAGEMENT IN AIR TRANSPORT
}

\author{
WYBRANE ASPEKTY ZARZĄDZANIA \\ BEZPIECZEŃSTWEM W TRANSPORCIE LOTNICZYM
}

\author{
Anna Stelmach \\ Warsaw University of Technology, Faculty of Transport \\ Politechnika Warszawska Wydzial Transportu \\ 00-662 Warszawa Koszykowa 75 \\ e-mail:ast@it.pw.edu.pl
}

\begin{abstract}
Question of assuring safety in civil aviation is closely related to development of technical means and organization of air transport. Requirements of international and European Union aviation law in safety management are differently defined and based on different methods.

The paper presents results of review of these methods in area of assuring and management of safety in air traffic. It also describes reactive and proactive methods and strategies of safety and risk management as well as tools and models of quality management system used for safety analysis.
\end{abstract}

Keywords: air traffic, air transport, safety standards

Streszczenie: Zagadnienie zapewnienia bezpieczeństwa w lotnictwie cywilnym jest ściśle związane z rozwojem środków technicznych i organizacji transportu lotniczego. Wymaganiem wspólnotowego i międzynarodowego prawa lotniczego jest zarządzanie bezpieczeństwem, różnie definiowane i oparte na różnych metodach. W artykule przedstawiono wyniki przeprowadzonego przeglądu metod w zakresie dotyczącym zapewnienia i zarządzania bezpieczeństwem w ruchu lotniczym. Opisano reaktywne i proaktywne metody i strategie zarządzania bezpieczeństwem oraz ryzykiem jak również narzędzia i modele systemu zarządzania jakością stosowane do analizy bezpieczeństwa.

Słowa kluczowe: ruch lotniczy, transport lotniczy, bezpieczeństwo 


\section{SOME ASPECTS OF SAFETY MANAGEMENT IN AIR TRANSPORT}

\section{Introduction}

Safety management issues include complex activities, which aim at minimizing the risk of losses and at the same time, take into consideration the relations among all causes and sources of potential threats.

The Safety Management System (SMS) [1] is a helpful tool for companies involved in air activities, which may be useful for achieving and maintaining an acceptable level of services' safety. The SMS ensures that all executed processes are covered by safety policy, which means a proper monitoring and a constant concern to remain within the frames of given safety standards.

In the air industry, many different institutions need to cooperate together: carriers, aircraft manufacturers, institutions providing air navigation services, airport managers etc. In practice, each of these institutions, basing on appropriate international legal regulations, needs to support a functioning system of safety management, which enables them to guarantee a high level of services' safety, however using different safety standards.

The issue of providing safety measures for civil aviation is closely connected to development of technical means and arrangement of air transport. Safety management is a requirement of EU and international legislation with respect to the Aviation Law. It is based on various methods and has various definitions. Requirements and recommendations regarding the safety in civil aviation are published, in particular, by the International Civil Aviation Organization, the European Civil Aviation Conference, the European Organization for the Safety of Air Navigation (EUROCONTROL) and European Aviation Safety Agency.

The aim of this article is to present a study on methods and strategies for safety and risk management as well as to describe tools and models of a quality management system used for safety analysis..

\section{Methods for safety management}

There are two methods for safety management. Both of them concern a reactive and proactive safety management in air transport. 
Reactive methods (and strategies) for safety management - such methods are oriented towards ensuring conformity with the Aviation Law regulations, which specify requirements and recommendations. These requirements, while applied in a uniform way, shall provide for safety in air traffic. The certification process, which is an objective and substantiated procedure for establishing conditions and the level of compliance with requirements, includes in particular the evaluation of:

- organization and operation methods,

- personnel qualifications and training programs,

- formal documentation and executive instructions,

- procedures and operation methods,

- technical means.

Reactive safety management based on measures and analysis of ensuing air occurrences, allow only for an approximate identification of potential threats and concealed dangerous conditions. Due to this fact, such methods are not effective and efficient enough. The used methods make impossible the identification of trends and forecasting of safety measures, as well as they exclude the possibility to identify the sources of threats and concealed dangerous conditions [5].

In case it turns out impossible to meet the requirements (incompatibility), it is necessary to report a deviation. It may be approved only on the basis of a positive outcome of the aeronautic study, which shall show that a balanced level of safety is ensured.

Proactive methods (and strategies) for safety management - are oriented towards preventing the air occurrences through collecting information from various sources, which may serve as indicators for safety problems. Implementation of the proactive strategy for safety management is a symptom of belief that the risk of accidents may become minimized before it even occurs by undertaking necessary actions (corrective, preventive, improving) to reduce threats and risk. The basis for a proactive safety management lays in the formula for a constant and systematic undertaking of actions in the scope of:

- threats identification,

- risk analysis,

- carrying on actions commensurate with the obtained results of preventive and/or corrective activities, defined as risk management based on risk analysis (or in other words, risk control). 


\section{Risk analysis in the process of safety management for air transport}

Risk analysis is a continuous and repeatable process consisting of:

- threats identification (collecting of quantitative and qualitative data),

- analysis of data and measures:

- probability of air occurrences,

- effects of air occurrence,

- estimation of the risk level (for example, using the Risk Tolerance Matrix). Following the results of examinations after numerous air accidents, a predominant cause of accidents was classified as human factor. This factor is defined as unintentional human mistake, which provokes threats. Today, the human factor is one of the most important components of the safety management system, implemented in the proactive formula. In the theory of safety management systems, the human factor stands in the center of divagations and is considered as multi-dimensional.

Regarding the human being, a basis for the proactive safety management is a team safety culture. This phenomenon is created through an adequate policy (together with aims and priorities regarding the safety), as well as training, motivating and increasing the employees' commitment, developing the scope of responsibilities and code of conduct in case of danger. Creating a team safety policy enables for a significant increase of effectiveness of unintentional human mistakes' control and establishment of the range of mistakes' tolerance. The effect of such actions is a minimization of the threat probability and potential risk of losses, resulting from an unintentional mistake made by a human being.

Methods of risk analysis consist mainly in identification of threats related to risk. They may be carried according to various schemes. Several methods of risk analysis are defined:

a. Failure Mode and Effects Analysis - this method is often used for analyzing the risk related to the exploitation of compound technical objects. While analyzing the risk through this method, the object is split into elements or sets and its block scheme is made. Each of the elements (sets) is analyzed separately.

b. Fault Tree Analysis - this method is used for defining relations between causes and effects. While conducting the risk analysis using the FTA method, the highest occurrence should be defined, which means a maximum discouraging situation in the considered process, such as explosion, death of a person, injury etc. 
c. Event Tree Analysis - the rules for risk analysis through the event tree method are similar to the rules of fault tree method, however its direction is different. The analysis begins with establishing possible causes (threat factors) and leads to specifying threats resulting from it.

The selection of a method depends on how complex the analyzed system is, on the type of activity and the current stage (design, implementation, normal activity).

\section{Tools for quality management used in the risk management system}

Proactive and systemic risk management needs to be comprehensive, interdisciplinary and based on a process approach.

The implementation and maintenance of the management system requires suitable resources for a management system, which are:

- management rules (generally formulated policy, aims and approach towards safety assurance),

- management methods (planned, repeatable and based on scientific grounds for task realization),

- management tools (for data collecting and analyzing).

Table. 1. Review of features and examples for resources of a management system

\begin{tabular}{|c|c|c|}
\hline Resource & Features & Examples \\
\hline Rules & $\begin{array}{l}\text { 1. Long-term effect - determine the } \\
\text { strategy. } \\
\text { 2. Go beyond the scope of activity } \\
\text { of the entity. } \\
\text { 3. Do not provide the operational } \\
\text { guidelines. } \\
\text { 4. The results of application are } \\
\text { hard to be subject to current } \\
\text { evaluation. }\end{array}$ & $\begin{array}{ll}- & \text { PDCA rule of Deming's circle, } \\
- & \text { Kaizen's rule - ,constant im- } \\
\text { provement of processes”, } \\
\text { - Crosby's rule } \\
\text { „zero defects”. }\end{array}$ \\
\hline Methods & $\begin{array}{ll}\text { 1. } & \text { Medium-term effect. } \\
\text { 2. } & \begin{array}{l}\text { Allow for creating the quality of } \\
\text { design and quality of execution. }\end{array} \\
\text { 3. } & \begin{array}{l}\text { Based on generally accepted } \\
\text { conduct algorithms. }\end{array}\end{array}$ & $\begin{array}{ll}- & \text { QFD, } \\
- & \text { FMEA. }\end{array}$ \\
\hline Tools & $\begin{array}{l}\text { 1. Short-term effect - operational. } \\
\text { 2. The results of application are } \\
\text { visible ,almost" immediately, } \\
\text { but effective. } \\
\text { 3. Application requires to be com- } \\
\text { bined with methods. }\end{array}$ & $\begin{array}{ll}- & \text { block scheme, } \\
\text { - } & \text { Ishikawa's diagram } \\
\text { - } & \text { Pareto-Lorenzo's diagram, } \\
\text { - } & \text { histogram, } \\
\text { - } & \text { control sheets, } \\
\text { - } & \text { correlation graphs, } \\
\text { - } & \text { control chart. }\end{array}$ \\
\hline
\end{tabular}

Quality Function Deployment - is a method, which uses a matrix to present correlations between requirements (matrix lines) and the features of a 
planned product or the results of the process (matrix columns). It is complemented with additional tables and diagrams. It allows for identification of relations between the outcome of the process and the requirements, as well as the level of compatibility.

Failure Mode and Criticality Analysis - is an analytical method used for determining the cause and effect relations of potential discrepancies, taking into consideration the critical factors of risk. We operate with risk points RPN (Risk Priority Number):

$$
R P N=R \times Z \times W
$$

where:

$R$ - probability (frequency) of discrepancies (threat), estimated in $1 \div 10$ scale;

$Z$ - meaning of discrepancy (risk resulting from threat), estimated in $1 \div 10$ scale;

$W$ - probability of detecting the discrepancy (identification of threat) and taking up corrective and/or preventive actions, estimated in $1 \div 10$ scale.

Diagram Ishikawy is used for presenting a graphic analysis of relations between factors and effects in the process. This tool is based on "5M" approach, according to which the most significant factors affecting the course of the process, including safety, are: man, machine, method, material, management [5]. The application of this tool is often expanded with another, sixth "M" - measurement.

Diagram Pareto-Lorenza is used for determining trends of undertakings on the basis of identification of causes, which have the strongest impact on safety. It is created according to the algorithm:

1. Process monitoring.

2. Selection of measurable indicators.

3. Decreasing systematization of data with the process' result causes.

4. Calculating the accumulated percentage values for every cause.

5. Preparing a graph of accumulated percentage values.

6. Analyzing the graph in order to point out the causes with the strongest impact on the result of the process - safety.

Control sheets are a quality tool used for collecting and ordering data regarding a specific process outcome. The arrangement of the sheet displays the aim, for which it has been created. 
Correlation graph is a quality tool used for analysis of a graphically presented relation between two random variables $\mathrm{X}$ and $\mathrm{Y}$. The mathematical basis for this tool lays in the correlation coefficient $-r$ expressed by a quotient:

$r(X, Y)=\frac{E(X Y)-E(X) E(Y)}{\sqrt{D^{2}(X) D^{2}(Y)}}$

Properties of the correlation coefficient $-r$ :

if the random variables $\mathrm{X} \mathrm{i} \mathrm{Y}$ are independent, then $r(X, Y)=0$, $|r(X, Y)| \leq 1 ; \quad$ if $Y=a X+b$, then $|r(X, Y)|=1$

Shewart's control chart is a basic quality tool for statistic monitoring and improving the processes. The principle of running a control chart is based on sampling - collecting data, which measure the features (quality, time frames, safety) of the process and calculating for every sample of statistic measures, for example: arithmetical average, median, standard deviation. The purpose of using the control chart is verifying whether the process stays in a statistically regulated state [2]. A statistically regulated state describes a state when the variability between observed outcomes of the process may be attributed to a set of random causes as well as a state which is stable in time, or when there is no systemic variability.

The following types of Shewart's control charts are used:

1. control chart of the average value and gap $(\bar{x}-R)$,

2. control chart of the average value and standard deviation $(\bar{x}-\sigma)$,

3. control chart of the median and gap $(M e-R)$.

For example, using the control chart of the average value and gap $(\bar{x}-R)$ is based on the assumption of a regular layout of the random variable, i.e. having in mind the Central Limit Theorem. Running this chart requires determination of courses:

average value $\bar{x}$ abd:

- UCL - upper control limit:

$U C L=\bar{x}+A_{2} \bar{R}$

- UWL - upper warning limit:

$U W L=\bar{x}+A_{2}^{\prime} \bar{R}$

- CL - central line: 
$C L=\bar{x}=\frac{\sum_{i=1}^{n} \bar{x}}{n}$

- LWL - lower warning limit:

$L W L=\bar{x}-A_{2}^{\prime} \bar{R}$

- UWL - upper control limit:

$U W L=\bar{x}+A_{2}^{\prime} \bar{R}$

and gap $R$ :

$U C L=D_{4} \bar{R}$

$C L=\bar{R}$

$L C L=D_{3} \bar{R}$

and plotting those lines on the graphs.

\section{Conclusion}

Describing the aim of the research and monitoring the state of features, which determine the safety of air crafts in the air traffic with use of the presented statistical methods - ,quality tools", allows for an effective calculation of undertakings' trends with respect to the operational management, for example of an airport. Both with reference to reactive and proactive standards for safety ensuring, a three-level scale may be used for describing the current risk level.

\section{References}

1. Annex 13 ICAO to the Convention on International Civil Aviation Aircraft Accident and Incident Investigation.

2. Hamrol A., Mantura W.: Zarzqdzanie jakościq-teoria i praktyka. PWN, Warszawa, 1998.

3. Jadźwiński J, Borgoń J.: Niezawodność eksploatacyjna i bezpieczeństwo lotów. WKiŁ Warszawa, 1989.

4. Malarski M., Kozłowski M.: Metody badania przyczyn i skutków zagrożenia bezpieczeństwa ruchu lotniskowego. XXXIII ZSN Szczyrk, 2005.

5. Winiewski A., Kozłowski M.: Diagram Ishikawy w systemie zarzadzania bezpieczeństwem w porcie lotniczym. XXXIV ZSN Szczyrk, 2006. 


\section{SOME ASPECTS OF SAFETY MANAGEMENT IN AIR TRANSPORT}

\section{Wstęp}

Zarządzanie bezpieczeństwem to kompleksowe działania zmierzające do minimalizacji ryzyka powstania strat uwzględniające współzależność wszystkich przyczyn i źródeł potencjalnych zagrożeń.

Dla firm prowadzących działalność lotniczą użytecznym narzędziem do osiagnięcia i utrzymywania akceptowalnego poziomu bezpieczeństwa usług jest System Zarządzania Bezpieczeństwem SMS (Safety Management System) [1]. SMS zapewnia, że wszystkie realizowane procesy objęte są polityką bezpieczeństwa a więc odpowiednim monitoringiem i ciagłą troską o to aby ich realizacja nie wykraczała poza określone normy bezpieczeństwa.

W branży lotniczej współdziała wiele różnych instytucji: przewoźnicy, producenci statków powietrznych, instytucje świadczące usługi żeglugi powietrznej, zarządzający lotniskami itp. Praktycznie każda z nich, na mocy odpowiednich przepisów międzynarodowych, utrzymuje funkcjonujący system zarządzania bezpieczeństwem gwarantując tym samym wysoki poziom bezpieczeństwa swoich usług stosując jednak różne standardy bezpieczeństwa.

Zagadnienie zapewnienia bezpieczeństwa w lotnictwie cywilnym jest ściśle związane z rozwojem środków technicznych i organizacji transportu lotniczego. Wymaganiem wspólnotowego i międzynarodowego prawa lotniczego jest zarządzanie bezpieczeństwem, różnie definiowane i oparte na różnych metodach. Wymagania i zalecenia $\mathrm{w}$ zakresie zapewnienia bezpieczeństwa $\mathrm{w}$ lotnictwie cywilnym publikowane są $\mathrm{w}$ szczególności przez: Organizację Międzynarodowego Lotnictwa Cywilnego (ICAO), Europejską Konferencję Lotnictwa Cywilnego (ECAC), Europejską Organizację do Spraw Bezpieczeństwa Żeglugi Powietrznej (EUROCONTROL) oraz Europejską Konferencję Bezpieczeństwa Lotniczego (EASA).

Celem artykułu jest studium na temat metod i strategii zarządzania bezpieczeństwem oraz ryzykiem jak również przedstawienie narzędzi i modeli systemu zarządzania jakością stosowanych do analizy bezpieczeństwa. 


\section{Metody zarządzania bezpieczeństwem}

Istnieją dwie metody zarządzania bezpieczeństwem. Dotyczą one reaktywnego i proaktywnego zarządzania bezpieczeństwem w transporcie lotniczym.

Reaktywne metody (i strategie) zarzqdzania bezpieczeństwem - zorientowane są na zapewnienie zgodności z wymaganiami aktów prawa lotniczego, specyfikujących wymagania i określających zalecenia, których jednolite zastosowanie ma zapewnić bezpieczeństwo ruchu lotniczego. Powszechną praktyką oceny stopnia spełnienia wymagań i zachowania trwałej zdolności do działania z wymaganiami bezpieczeństwa jest certyfikacja. Proces certyfikacji obejmuje:

- organizację i metody działania,

- kwalifikację personelu i programy szkolenia,

- dokumentację formalną i instrukcje wykonawcze,

- procedury,

- środki techniczne.

Reaktywne zarządzanie bezpieczeństwem oparte na miernikach i analizie zaistniałych zdarzeń lotniczych, umożliwia tylko przybliżone identyfikowanie potencjalnych zagrożeń i ukrytych warunków niebezpiecznych, co powoduje, że takie metody są mało skuteczne i nieefektywne. Stosowane metody uniemożliwiają identyfikację trendów i prognozowanie mierników bezpieczeństwa, jak również wykluczają możliwość zidentyfikowania źródeł zagrożeń i ukrytych warunków niebezpiecznych [5].

W przypadku niemożności spełnienia wymagania (niezgodność) konieczne jest zgłoszenie odstępstwa, które może zostać zatwierdzone tylko na podstawie pozytywnego wyniku studium aeronautycznego, które wykaże, że zapewniony jest równoważny poziom bezpieczeństwa.

Proaktywne metody (i strategie) zarzqdzania bezpieczeństwem zorientowane są na zapobieganie zdarzeniom lotniczym na drodze dokładnego zbierania informacji z różnych źródeł, które mogą być wskaźnikiem problemów bezpieczeństwa. Wdrażanie proaktywnej strategii zarządzania bezpieczeństwem jest przejawem przekonania, że ryzyko wypadku może zostać zminimalizowane zanim on nastapi poprzez podjęcie koniecznych działań (korygujących, zapobiegawczych, doskonalących) dla minimalizacji zagrożeń i redukcji ryzyka. Podstawę proaktywnego zarządzania bezpieczeństwem 
Wybrane aspekty zarzqdzania bezpieczeństwem...

stanowi formuła ciagłego i systematycznego podejmowania działań w zakresie:

- $\quad$ identyfikacji zagrożeń,

- $\quad$ analizy ryzyka,

- $\quad$ podejmowania adekwatnych do otrzymanych wyników działań zapobiegawczych i/lub korygujących, określanych wspólnym mianem zarządzanie ryzykiem, opartym na analizie ryzyka (lub inaczej kontroli ryzyka).

\section{Analiza ryzyka $w$ procesie zarządzania bezpieczeństwem w transporcie lotniczym}

Analiza ryzyka to ciągły i powtarzalny proces, na który składa się:

- identyfikacja zagrożeń (gromadzenie danych ilościowych i jakościowych),

- analiza danych i mierników:

- prawdopodobieństwo wystapienia zdarzenia lotniczego,

- skutki zaistnienia zdarzenia lotniczego,

- oszacowanie poziomu ryzyka.

Jak dowodzą wyniki badania licznych wypadków lotniczych dominująca przyczyna ich zaistnienia została sklasyfikowana jako czynnik ludzki, definiowany jako nieintencjonalny błąd ludzki, którego popełnienie powoduje wystąpienie zagrożeń. Współcześnie czynnik ludzki należy do grupy najważniejszych komponentów systemu zarządzania bezpieczeństwem, wdrażanego $\mathrm{w}$ formule proaktywnej. W odniesieniu do czynnika ludzkiego podstawę proaktywnego zarządzania bezpieczeństwem stanowi zespolowa kultura bezpieczeństwa. Jest ona kreowana poprzez ustanowienie polityki jak również szkolenie, motywowanie i zwiększanie zaangażowania pracowników, określenie zakresu odpowiedzialności i sposobu postępowania w przypadku wystapienia zagrożenia. Efektem tych działań jest minimalizacja prawdopodobieństwa wystąpienia zagrożenia i potencjalnego ryzyka strat wynikających z popełnienia przez człowieka nieintencjonalnego błędu.

Metody analizy ryzyka polegają głównie na identyfikacji zagrożeń, z którymi to ryzyko jest związane. Mogą być wykonane według różnych schematów. Definiuje się kilka metod analizy ryzyka:

a. Failure Mode and Effects Analysis - metoda stosowana jest często do analizy ryzyka związanego z eksploatacją złożonych obiektów technicznych. W analizie ryzyka tą metodą obiekt dzieli się na elementy lub zespoły i sporządza jego schemat blokowy. Każdy z elementów (zespołów) jest analizowany oddzielenie. 
b. Fault Tree Analysis - metoda do określania związków między przyczynami i ich skutkami.

c. Event Tree Analysis - zasady analizy ryzyka metodą drzewa zdarzeń są podobne jak w analizie przeprowadzanej metoda drzewa błędów. Analizę rozpoczyna się od ustalenia możliwych przyczyn (czynników zagrażających) i prowadzi do określenia wynikających z nich zagrożeń.

Wybór metody zależy od tego jak złożony jest analizowany system, od specyfiki jego pracy i etapu, na jakim się znajduje (projektowania, wdrażanie, normalna praca).

\section{Narzędzia zarządzania jakością stosowane w systemie zarządzania bezpieczeństwem}

Proaktywne i systemowe zarządzanie bezpieczeństwem musi być oparte na podejściu procesowym, wszechstronne i interdyscyplinarne.

Wdrożenie i utrzymywanie systemu zarządzania wymaga zapewnienia zasobów systemu zarządzania, do których należą:

- zasady zarządzania (ogólne sformułowanie polityki, celów i podejścia do zapewnienia bezpieczeństwa),

- metody zarządzania (planowe, powtarzalne i oparte na naukowych podstawach sposoby realizacji zadań),

- narzędzia zarządzania (do zbierania i analizy danych).

Tabela. 1. Przegląd cech i przykładów zasobów systemu zarządzania

\begin{tabular}{|c|c|c|}
\hline Zasób & Cechy & Przykłady \\
\hline Zasady & 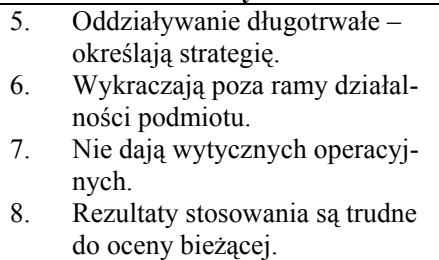 & $\begin{array}{ll}\text { - } & \text { Zasada PDCA koła Deming'a, } \\
\text { - } & \text { Zasada Kaizen'a - ,,ciagłego } \\
\text { doskonalenia procesów”, } \\
\text { - } \quad \text { Zasada Crosby'ego } \\
\text {,zera defektów”. }\end{array}$ \\
\hline Metody & 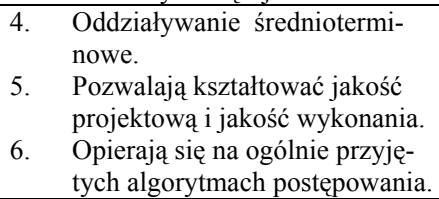 & $\begin{array}{ll}- & \text { QFD, } \\
- & \text { FMEA. }\end{array}$ \\
\hline Narzędzia & $\begin{array}{ll}4 . & \begin{array}{l}\text { Oddziaływanie krótkotrwałe - } \\
\text { operacyjne. }\end{array} \\
\text { 5. } & \text { Wyniki stosowania widoczne } \\
\text {,prawie" natychmiast, ale efek- } \\
\text { tywne. } \\
\text { 6. } \begin{array}{l}\text { Wykorzystanie wymaga połą- } \\
\text { czenia z metodami. }\end{array}\end{array}$ & $\begin{array}{ll}- & \text { schemat blokowy, } \\
- & \text { diagram Ishikawy, } \\
- & \text { diagram Pareto-Lorenza, } \\
- & \text { histogram, } \\
- & \text { arkusze kontrolne, } \\
- & \text { wykresy korelacji, } \\
- & \text { karta kontrolna. } \\
\end{array}$ \\
\hline
\end{tabular}


Quality Function Deployment - jest metodą wykorzystującą macierz pokazującą współzależności zachodzące pomiędzy wymaganiami (wiersze macierzy) i cechami planowanego produktu lub wynikami procesu (kolumny macierzy), uzupełniona dodatkowymi tablicami i diagramami. Umożliwia identyfikację relacji pomiędzy wynikami procesu a wymaganiami, oraz stopień zgodności.

Failure Mode and Criticality Analysi - jest analityczną metodą ustalania związków przyczynowo-skutkowych powstawania potencjalnych niezgodności z uwzględnieniem krytyczności czynników ryzyka. Operuje punktami ryzyka - RPN (Risk Priority Number):

$R P N=R \times Z \times W$

gdzie:

$R$ - prawdopodobieństwo (częstość) wystapienia niezgodności (zagrożenia), szacowane w skali $1 \div 10$;

$Z$ - znaczenie niezgodności (ryzyko wynikające z zagrożenia), szacowane w skali $1 \div 10$;

$W$ - prawdopodobieństwo wykrycia niezgodności (zidentyfikowania zagrożenia) i podjęcia działań korygujących i/lub zapobiegawczych, szacowane w skali $1 \div 10$.

Diagram Ishikawy służy do graficznej analizy powiązań między czynnikami i skutkami w procesie. Narzędzie to oparte jest na podejściu „5M”, według którego najważniejszymi czynnikami wpływającymi na przebieg procesu, w tym bezpieczeństwo są: człowiek, maszyna, metoda, materiał, zarządzanie [5] . Zastosowanie tego narzędzia często jest rozszerzane o szóste „M" - pomiar.

Diagram Pareto-Lorenza stosowany jest do wyznaczenia kierunków przedsięwzięć na podstawie identyfikacji przyczyn, które mają największy wpływ na bezpieczeństwo. Budowany jest według algorytmu:

1. Monitorowanie procesu.

2. Dobór wskaźników mierzalnych.

3. Uszeregowanie malejące danych o przyczynach wyniku procesu.

4. Wyznaczenie skumulowanych wartości procentowych każdej przyczyny.

5. Sporządzenie wykresu skumulowanych wartości procentowych.

6. Analiza wykresu w celu wyznaczenia przyczyn o największym wpływie na wynik procesu - bezpieczeństwo. 
Arkusze kontrolne są narzędziem jakości wykorzystywanym do zbierania i porządkowania danych dotyczących konkretnego wyniku procesu. Układ arkusza eksponuje cel, dla którego został stworzony.

Wykres korelacji jest narzędziem jakości wykorzystywanym do analizy graficznie przedstawionej zależności zachodzących pomiędzy dwiema zmiennymi losowymi $X$ i $Y$. Matematyczną podstawę tego narzędzia stanowi wspótczynnik korelacji - $r$ wyrażony ilorazem:

$$
r(X, Y)=\frac{E(X Y)-E(X) E(Y)}{\sqrt{D^{2}(X) D^{2}(Y)}}
$$

Własności współczynnika korelacji - $r$ :

jeżeli zmienne losowe $X$ i $Y$ są niezależne to $r(X, Y)=0,|r(X, Y)| \leq 1$

jeżeli $Y=a X+b$ to $|r(X, Y)|=1$

Karta kontrolna Shewarta to podstawowe narzędzie jakości statystycznego monitorowania i doskonalenia procesów. Zasada prowadzenia karty kontrolnej opiera się na próbkowaniu - pobieraniu danych wymiarujących cechy (jakościowe, czasowe, bezpieczeństwa) procesu i obliczenie dla każdej próbki miar statystycznych. Celem stosowania karty kontrolnej jest ocena, czy proces znajduje się w stanie statystycznie uregulowanym [2]. Stan statystycznie uregulowany, to stan w którym zmienność między obserwowanymi wynikami procesu może być przypisana zespołowi przyczyn losowych. Stosowane są następujące rodzaje kart kontrolnych Shewarta:

1. karta kontroli wartości średniej i rozstępu $(\bar{x}-R)$,

2. karta kontroli wartości średniej i odchylenia standardowego $(\bar{x}-\sigma)$,

3. karta kontroli mediany i rozstępu $(M e-R)$.

Przykładowo, zastosowanie karty kontroli wartości średniej i rozstępu $(\bar{x}-R)$ oparte jest na założeniu rozkładu normalnego zmiennej losowej, np. na mocy Centralnego Twierdzenia Granicznego. Prowadzenie tej karty wymaga wyznaczenia torów:

wartości średniej $\bar{x}$ oraz:

- UCL - górna granica kontrolna:

$U C L=\bar{x}+A_{2} \bar{R}$ 
- UWL - górna granica ostrzegawcza:

$U W L=\bar{x}+A_{2}^{\prime} \bar{R}$

- CL - linia centralna:

$C L=\bar{x}=\frac{\sum_{i=1}^{n} \bar{x}}{n}$

- LWL - dolna granica ostrzegawcza:

$L W L=\bar{x}-A_{2}^{\prime} \bar{R}$

- UWL - dolna granica kontrolna:

$U W L=\bar{x}+A_{2}^{\prime} \bar{R}$

i rozstępu $R$ :

$U C L=D_{4} \bar{R}$

$C L=\bar{R}$

$L C L=D_{3} \bar{R}$

oraz naniesienie na wykres tych linii.

\section{Podsumowanie}

Określenie celu badań i monitorowanie stanu cech czynników determinujących bezpieczeństwo statków powietrznych w ruchu lotniczym, przedstawionymi metodami statystycznymi - „narzędziami jakości”, umożliwia efektywne wyznaczenie kierunków przedsięwzięć na poziomie operacyjnego zarządzania np. lotniskiem. Zarówno w odniesieniu do reaktywnego jak i proaktywnego standardu zapewnienia bezpieczeństwa można użyć trzy stopniowej skali i opisać aktualny poziom ryzyka.

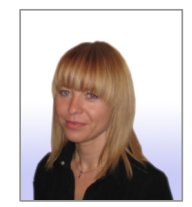

Dr Ing. STELMACH Anna, Warsaw University of Technology, Faculty of Transport, Department of Air Transport Engineering, specialisation: air transport engineering, operation research. Several publications in field. 
